\title{
Growth respond and nutrient utilization of Clarias gariepinus fed bean cake
}

\author{
Chiokwe, G. I. and Solomon, R. J.* \\ Department of Biological Sciences, Faculty of Science, University of Abuja, Abuja - Nigeria. \\ *Corresponding author. Email: johnsol2004@yahoo.com
}

Copyright (c) 2017 Chiokwe and Solomon. This article remains permanently open access under the terms of the Creative Commons Attribution License 4.0, which permits unrestricted use, distribution, and reproduction in any medium, provided the original work is properly cited.

Received 1st May, 2017; Accepted 19th May, 2017

\begin{abstract}
The study was conducted to assess the effect of bean cake on the growth of Clarias gariepinus. The feed was formulated and fed to Clarias gariepinus for a period of 8 weeks while using Coppens and Multifeed as the controls. Fishes were fed twice daily at $4 \%$ body weight/day. There were 12 fishes per experimental tank. The result obtained from the study indicated that the highest growth rate occurred in the fishes fed with coppens and multifeed and the lowest being Bean cake. The analysis of the result done using ANOVA however showed that there was no significant difference ( $p>0.05$ ) in the mean weight, mean length, food conversion efficiency (FCE) and the survival rates (SR), but showed a significant difference $(p<0.05)$ in the weight gain, length gain, specific growth rate $(S G R)$ and mean growth rate (MGR). Bean cake could be used for the sustenance of Clarias gariepinus but not for optimum growth.
\end{abstract}

Key words: Bean cake, Clarias gariepinus, coppens, growth rate, multifeed.

\section{INTRODUCTION}

Fish is an important source of both food and income to many people in developing countries like Nigeria. Fish is known to be the one of the main source of protein to man providing about 17 to $38 \%$ of total of total protein intake in various countries and about $40 \%$ of normal protein intake of the average Nigeria (Dada and Gnanados, 1983). It also provides fat, minerals, oil and vitamins which are accessory food factors whose deficiency leads to malnutrition and in man. In Africa, as much as $5 \%$ of the population, some 35million people depends wholly or partly on the fisheries sector for their livelihood (FAO, 1996a). It is estimated that by 2050, when world population is projected to be over 9 billion, Africa will have to increase food production by over $300 \%$, Latin America by $80 \%$ and Asia $70 \%$ to provide minimally adequate diets for the projected population of 2 billion, 810 million and 54billion people in the respective regions (Anon, 1997).

The consumption and demand for fish as a cheap source of protein on the increase in Africa, because of the level of poverty in the land. The vast majority of the fish supply in most cases comes from the rivers in the continent. While capture fisheries based on species that are presently exploited seem to have reached their natural limit (FAO, 1996b), there is considerable potential to expand aquaculture in Africa in order to improve food security (Kapetsy, 1994; Engel, 1997; Jamiu and Ayinla, 2003). Although potentials abound in the continent for the development of viable fish farming, one of the major hindrances to the development of aquaculture industry in Africa is the lack of locally produced fish feed. Fish requires high quality feed for growth and attainment of market size within the shortest possible time. Therefore local production of fish feed is very crucial to the development and sustainability of aquaculture in Africa.

Feed accounts for over two third of the variable cost of fish culture operation in an intensive management system (Akiyama, 1988; Eyo, 1990).

The African catfish (Clarias gariepinus) is choice fish species in Nigeria. It commands high demands from consumers and is mostly preferred by aquaculture. This is due to the ideal characteristics of this species (Eding and Kamstra, 2001), which includes high growth rate at high stocking densities, a high food conversion, good food quality and smoking characteristics as well as year round production (Ita, 1985). Fish culture production in 
Nigeria includes stocking of lakes and production in ponds, cages and tanks (Ita, 1985). Pond culture is the most prevalent (Akinwole and Faturoti, 2006). Virtually all aspects of ponds culture of African catfish (Clarias gariepinus) in Nigeria has been developed and documented to ensure profitable production of the species. The appreciable quality of water and large expanse of land required for pond culture abound in Nigeria, but however fish feed has been a limitation for its expansion.Beans is one of the most important food legume crops in the semi-arid tropics covering Africa, Asia, Southern Europe and Central and South America. Beans are drought resistance tolerant and warm weather crop. They are well adapted to the drier region of the tropics, where other legumes do not perform well. Beans are high in protein and are readily available in the market. Beans are used for various things for example; Beans could be boiled and eaten with other food like rice, bread. They are also boiled with sauce and eaten alone; beans are the favorite meal of school children because of their sustainability and high protein content, they are also eaten as cake, popularly called akara. Beans are also fed to livestock such Poultry birds and so on (Singh et al., 2003).

Despite the fact that beans is rich in protein which is what fish need for optimum growth, beans can be used as alternative supplement feed. However, no attention has been drawn to the use of beans as an alternative supplement. More so, researchers seemed to have neglected the potentials that beans hold for fish growth. Consequently, this research work is undertaken with a view to establishing the effects of beans on the growth of Clarias gariepinus.

Aquaculture development and growth in Africa have been on low ebb despite the vast aquatic resources that abounds in the continent. Since the introduction of aquaculture to Africa, some decades ago, there have been a lot of innovations, technological advancement and progress in the areas of genetics, seed propagation, pond construction and farm management in general. Despite breakthroughs recorded in these areas, most farmers in Africa still rely heavily on imported feed ingredients and fish feeds from European countries, which makes fish farming expensive as fish feed accounts for at least $60 \%$ of the total cost of production (Jamiu and Ayinla, 2003). This has contributed in no small measure to the slow pace at which aquaculture is advancing in Africa. This project, however reviewed critically the potentials of locally manufactured fish feed in enhancing, improving and sustaining aquaculture development in Nigeria and Africa at large.

\section{Aquaculture development in Africa}

Aquaculture development in Africa is insignificant compared to the rest of the world (Changadeya et al.,
2003). According to Hetch (2000) the entire continent contributed only $0.4 \%$ to the total world aquaculture production for the period 1994 to 1995. In the year 2000 it contributed a mere $0.97 \%$ of the total global aquaculture (FAO, 2003).

Although, the history of aquaculture is relatively recent in sub-saharan Africa compared to Asia and some other parts of the world. Most known aquaculture systems have been introduced over the last 35years (FAO, 1996a, 1996c). The growth, expansion and production of aquaculture in northern part of Africa especially Egypt is more advanced in techniques and technicalities in comparison to the sub- Saharan regions (FAO, 2003).

In sub-Saharan regions, aquaculture in most places is still essentially rural, secondary and part time activity taking place in small farms with small fresh water ponds (FAO, 1996a). The systems that are generally practiced range from extensive to semi intensive cultural systems with limited fish yield, which are mostly consumed directly or sold locally (CIFA, 1998). Almost all fishing is carried out by rural small scale operators in small fresh water ponds as a secondary activity to agriculture. Although there is abundant potential for the development and expansion of aquaculture in this region, factors such as the novelty of aquaculture, the general poor economic conditions in most countries and the relative paucity of entrepreneurial skills and credit facilities hamper its development (FAO, 1997). Aquaculture development in most African countries is primarily focused on socioeconomic objectives such as nutritional improvement in rural areas, income generation, diversification of farm activities and creation of employment especially in rural communities where opportunities for aquaculture in northern part of Africa are limited (CIFA, 1998). This approach over the years has resulted in sustained aquaculture growth in some African countries such as Ivory Coast, Egypt, Ghana, Malawi, Nigeria, and Zambia (Jamiu and Ayinla, 2003). While there is still room for enhancing aquaculture production in Africa through improved production systems, genetics and general farm management principles, the desired and expected growth of aquaculture to meet the ever increasing demand for fish and satisfy its socio-economic functions is only achievable through cost effective and high quality fish feed.

\section{Aquaculture development in Nigeria}

Despite the fact that fish farming started in Nigeria over fifty years ago, it is not until very recently that aquaculture made substantial contribution to domestic fish supply. After many years of dormancy, the fisheries and aquaculture sector in Nigeria has been brought to the fore front of the national development agenda. Apart from ongoing activities of the presidential initiative on fisheries and aquaculture development, Nigeria also hosted the 
NEPAD "Fish for All summit" in Abuja in August 2005. This summit was a major success with the participation of 30 countries and international organizations. It is worthwhile to note the active participation and exhibition mounted by CAFAN at the summit which concluded by adopting the "Abuja Declaration" on sustainable fisheries and aquaculture development for Africa and the NEPAD plan of action.

The role of fishing in realizing food security in Nigeria cannot be overstated. It accounts for a major source of food protein. For example, fishery products domestic consumption provides approximately $22 \%$ of the protein requirement in Nigeria. It also generates employment for 36 million people directly through aquaculture. This means that any attempt to neglect fishing by the government maybe to our own peril (FAO, 2003). Interestingly, demand for fish has continued to increase, not only in Nigeria but also worldwide. Despite that, marine capture historically still accounts for over $80 \%$ of the world fish supply, however the capture fisheries have not been able to meet up with the growing demand due to increased fishing pressure and the resultant over-fishing syndrome (FAO, 2003). It has been postulated by FAO, that if Nigeria is to bridge the serious fish supply gap, the country must invest heavily in modern systems of aquaculture as well as poly-culture for rural communities, while providing enhanced capacities for capture fisheries development. There is no doubt that Nigeria possesses a good environment rich enough to stimulate growth in aquaculture given the right attitude by the government.

The underdeveloped aquaculture sector has the potential of 0.65 to 1.2 million tonnes of fish production annually in Nigeria. But it is presently producing 16.619 to 25.264 tonnes annually and it is produced mainly from outdoor, dugout extensive fish ponds, and it is basically $3 \%$ of the country's fish production potentials. Outdoor dugout pond farming has always been misconstrued as cheap and easy to operate due to lack of solid infrastructural requirements, low maintenance cost and low feeding costs.

According to the Nigerian institute of oceanography and Marine Research, the country has 1,000,000 hectares in fresh water of swamp suitable for aquaculture. This sounds as good news for fish farmers, however, the exploitation of this potentials remains minimal. For instance, an estimated area dedicated to fish farming in 1998 was given as about 5,000 hectares in fresh water and 230 hectares in brackish water. Production estimate was put at 1 tonne per hectare per year for small scale ponds and 2 to 4 tonnes per hectares per year for commercial farmers. This production was however achieved by using low semi-intensive fish farming culture level. The development of semi-intensive fish farming in Nigeria lies in the establishment of fish culture projects; such projects would increase fish production by $656: 815$ metric tonnes yearly. Due to the location of the fresh water swamps and the mangrove swamp in Niger delta, the rudimentary level of aquaculture development in Nigeria and particularly in Niger delta region is of great concern, especially when the potential for its development remains attractive.

\section{Aquaculture and food security in Africa}

Nutritionally, fish is one of the cheapest and direct sources of protein and micronutrient for millions of people in Africa (Ben et al., 2005), with steady decline in capture fisheries, aquaculture is a readily, veritable tool in the provision of fish eaten all over the continent. Unlike some other animal products, fish is widely acceptable. Its acceptability cuts across social, cultural and religious background. To maintain food fish consumption at the present level of 5 to $45 \mathrm{~kg}$ per person per year depending on the country, supplies of fish must increase tremendously. However, with the current supply trends combined with ever increasing population, the per capita consumption of fish in Africa is stagnating and in subsaharan Africa has fallen drastically (Muir et. al., 2005). To arrest this deplorable condition and boost production of fish, aquaculture remains the only feasible option that can sustain adequate fish supply in Africa.

\section{Fish feed development}

Fish feed technology is one of the least developed sector of aquaculture particularly in Africa and other developing countries of the world (FAO, 2003). Feed is one of the major input in aquaculture production, it is one of the fundamental challenges facing the development and growth of aquaculture in the African continent. Fish feed development in Sub-Saharan Africa has not made a significant progress in aquaculture as expected.

According to Hetch (2002), it is observed that the research on inexpensive feed ingredients has not contributed greatly to aquaculture development in Africa and suggested that more research on how best plant protein can be used as fish feed, play very vital role in aquaculture growth and expansion. In fact, it is a major factor that determines the profitability of aquaculture venture. Jamiu and Ayinla, (2003) reported that feed accounts for at least $60 \%$ of the total cost of fish production in Africa, which to a large extent determines the viability and profitability of fish farming enterprise. As aquaculture becomes intensive, most farmers in Africa depend largely on imported fish feed from European countries for the productivity and sustainability of the industry. For example, in Nigeria an estimated 4,000 tonnes of quality fish feed are imported into the country each year (AFP, 2007). This has contributed in no small way in increasing the total cost of production which will ultimately translate to high cost of fish, thereby making it expensive for the teeming population of the poor people 
living in Sub-Saharan Africa. In some countries like Kenya, Namibia, Malawi, Nigeria, Uganda, Madagascar, Ghana and Cote D'ivoire, where little quality of fish feeds are produced locally, the quality is very poor and production rate inconsistent. This corroborated the submission of Jamiu and Ayinla, (2003) that the low quality of fish feed and its attendant high cost are the major factor limiting the development of aquaculture in Africa. Hence, research in fish nutrition that will utilize locally available ingredients and fabricated equipment without reducing the quality of the feed is urgent and crucial to the overall success of aquaculture development, growth and expansion in Africa. For many aquaculture ventures to be viable and profitable, it must have a regular and adequate supply of balanced artificial diet for the cultured fishes. This is so because the dissolved nutrient environment are seasonal and might be insufficient or may not occur in required proportion to meet the nutritional demand of cultured fishes (Ugwumba and Ugwumba, 2003). There is therefore the need to develop and encourage fish farmers to make use of ideal pond fertilization programs, non-conventional feed resources, feed stuff processing, refinement and formulation that take cognizance of the requirement of the various species and their stages. In comparison to livestock feeds, fish feeds are unique in that they are pelleted and the size of the pellet depends to a large extent on size and age of the fish involved. Fish feed is very important in the efficiency and overall performance of fish in the pond and least lost feed production which will reduce the cost of production of fish. This is why any attention towards the production of effective and cheap feed will benefit fish farmers in Nigeria and Africa at large. The feed produced and used widely in Africa are categorized into conventional and non-conventional feed stuff. The categorization is based on the availability and acceptability of the feed stuff involved.

Literature on the use of beans as fish feed has been scarce and very difficult to come by. However, beans has been used to feed livestock, example; poultry birds, in some part of the country. The reported proximate analysis of beans (cowpea) showed that it has good potential as a source of protein for livestock feeding (Aremu, 1990). This study is therefore geared at exploring the possibility of using bean cake as fish feed, which if successful will cut down the cost of fish feed by replacing some of the expensive conventional fish feeds.

\section{MATERIALS AND METHODS}

\section{Experimental design}

Three rectangular transparent plastic tanks of $50 \times 26 \mathrm{~cm}$ $\times 26 \mathrm{~cm}$ with a capacity of 30 litres each were used for the experiment, with water level maintained at $35 \mathrm{~cm}(25$ litres). There were three treatments designated as Tank
A, Tank B, and Tank C. The species of fish used was Clarias gariepinus fingerlings of length 0 to $16 \mathrm{~cm}$ and weight 0 to $20 \mathrm{~g}$. The fishes were obtained from Mallam Dankishiya's fish farm and transported to the biological garden of University of Abuja between 6 to 8am to reduce mortality due to increased temperature. The fishes were acclimated for seven days in the biological garden. At the end of the acclimation period, the fishes were randomly selected and assigned to different tanks at a stocking rate of 12 fingerlings per tank. The fishes were starved for $24 \mathrm{hrs}$ to empty their gut content and prepare them for the experimental feed. This practice also helps to make the fish hungry and thus more responsive to the new diet. The fishes were fed $4 \%$ of their gross body weight per tank. Tank A was fed Coppens fish feed, Tank B was fed the formulated Bean Cake while Tank $C$ was fed Multifeed feed. The initial individual weight, length, mean length and mean weight were recorded. The aquaria were covered with mosquito net to prevent the fingerlings from jumping out, intrusion of insects and other foraging bodies (Lizard, geckos, spiders etc), fresh water was used throughout the experiment. Depleted water was replaced with fresh water of 25 litres after each cleaning. During cleaning, which involved scrubbing of the tanks with sponge, disinfection of the tanks using potassium permanganate to prevent contamination caused by the leftover food particles and washing with clean water?

\section{Weighing of fish}

The weight of the fishes were determined with the aid of a E-Zurich (Swiss made) weighing balance. Each fish was weighed individually thereafter the process was carried out weekly with the final weighing done at the end of the 8 weeks period of the experiment. The weighing of the fingerlings was done in order to get weight gain by the fingerlings weekly, after they have been subjected to feeding with the various feeds assigned to the various tanks at $4 \%$ gross body weight of the fishes per tank.

\section{Length of fish}

The lengths of the fishes were determined using a measuring board and a meter rule. This involved measuring the total length of individual fishes to the nearest centimeter. In measuring the length the fishes was placed on a board with its snout closed and touching the edge of the board, and the caudal fin pressed together and the reading taken from the graduated measuring board and recorded. This was done weekly to get the length gain per week.

\section{Feed Formulation}

The following materials were used to formulate the 
experimental bean cake feed; Ife brown beans, vitamin premix, methionine, lysine, bone meal and starch. The materials were procured from gwagwalada market and Agro Vet Stores. The beans and the bone meal were grinded individually in a grinding machine to obtain a fine powder.

The ingredients were mixed together thoroughly and formed into a paste using starch as the binding agent. The paste was pelleted using a locally made pelleter. The resultant pellets were sun dried for $48 \mathrm{~h}$. the dried feed was then taken for proximate analysis to the percentage compositions of crude protein, crude fat, crude fibre and ash. The remaining feed was then stored in an air tight container to prevent moisture from penetrating into it and also for subsequent feeding of the fingerlings.

\section{Feeding and measurement}

Three feeds were used for the experiment, they includes; coppens feed for aquaculture, multi feed for aquaculture, and the formulated experimental bean cake respectively. The feeds were assigned to various tanks; Tanks $A$ was fed coppens, Tank B was fed the experimental feed and Tank $C$ was fed multifeed. The fishes were fed $4 \%$ of their gross body weight per tank per day. The process involved weighing all the fishes in each tank using a weighing balance and calculating $4 \%$ of the gross body weight of the fishes per tank. This amount was measurement out from the bulk of the feed and fed to the fingerlings. The fingerlings were fed twice daily, half of the measured feed in the morning (7.00 to 9.00am) and the remaining half in the evening (5.00 to $7.00 \mathrm{pm})$. At the beginning of every new week, the process was repeated and thus the new gross weights were used. The duration for the experiment was 8weeks.

\section{Physiochemical Parameters}

During the first week of the experiment, the physiochemical parameters of the water were carried out daily. Parameters such as temperature, $\mathrm{pH}$, ammonia and dissolved oxygen were measured. This was to enable me know the time of the week to change the water (i.e when the water starts getting to toxic for the fingerlings survival). However, parameters such as the temperature were measured daily. Both the water temperature and the atmospheric temperature were read to the nearest $0^{\circ} \mathrm{C}$ with the aid of mercury in glass thermometer. The dissolved oxygen was determined once a week after the first week of daily measurements by titration with $0.1 \mathrm{NaOH}$ and the azide modification of the Winkler method (America Public Health Association, 1976), $\mathrm{pH}$ was determined with the aid of a digital $\mathrm{pH}$ meter. Ammonia was determined by a spectrophotometer, using the Phenolhydrochloride method, nitrite was measured using urinalysis test strip kit (Sterling, 1985).

\section{Nutrient utilization parameters}

Mean weight gain (\%): This was calculated as

MWG $(\%)=\frac{\text { rinal mean weight }}{\text { Initial mean weight }} \times 100$

Mean Length Gain (\%): This was calculated as

MLG $(\%)=\frac{\text { Final mean length }}{\text { Initial mean length }} x 100$

Specific growth rate (SGR)

$\mathrm{SGR}=\frac{\operatorname{Ln~WI}-\text { Ln wt }}{\mathrm{T}} \times 100$

Where, $\mathrm{WT}=$ Final Weight, $\mathrm{Wt}=$ Initial weight, $\mathrm{T}=\mathrm{Time}$ (Days) and $L n=$ Natural logarithm

Food conversion efficiency (FCE)

FCE $=\frac{\text { weignt Gain }}{\text { Feed Intake }} x 100$

Mean Growth Rate (MGR)

$\mathrm{MGR}=\frac{\mathrm{W} \angle-\mathrm{W} \perp}{0.5(\mathrm{~W} 2 \mathrm{~W} 1)} \times \frac{100}{\mathrm{t}}$

Where $\mathrm{W} 2=$ Final Weight, $\mathrm{W} 1=$ Initial Weight, $\mathrm{t}=$ Period of the experiment in days and $0.5=$ Constant.

Weight Gain: This was calculated as

W2 - W1

Where, $W 2=$ final mean weight value and $W 1=$ Initial mean weight value

Survival rate (SR)

$\mathrm{SR}=\frac{1 \text { otal nish number narvested }}{\text { Total fish number stocked }} x 100$

\section{Statistical analysis}

Analysis of growth data using analysis of variance (Oneway, ANOVA) was used for this study.

\section{RESULTS}

Results of production parameters for the three treatments are presented in (Tables 1, 3, and 5). While the physio- 
Table 1. Production Parameter For Treatment A (Coppens).

\begin{tabular}{|c|c|c|c|c|c|c|c|c|c|}
\hline Production Parameters & & & & & Weel & & & & \\
\hline & 0 & 1 & 2 & 3 & 4 & 5 & 6 & 7 & 8 \\
\hline Gross weight (g) & 110.42 & 141.78 & 176.196 & 217.92 & 268.304 & 275.231 & 307.373 & 333.861 & 386.210 \\
\hline Mean weight (g) & 9.201 & 11.815 & 14.683 & 18.160 & 21.942 & 25.021 & 27.943 & 30.351 & 35.110 \\
\hline Weight gain $(\mathrm{g})$ & 0.00 & 2.614 & 2.823 & 3.477 & 3.782 & 3.079 & 2.922 & 2.408 & 4.759 \\
\hline Total length (cm) & 114.24 & 138.108 & 152.196 & 176.508 & 195.348 & 207.90 & 232.562 & 255.431 & 278.564 \\
\hline Mean length (cm) & 9.520 & 11.509 & 12.683 & 14.709 & 16.279 & 18.900 & 21.142 & 23.221 & 25.324 \\
\hline Length gain (cm) & 0.00 & 1.989 & 1.174 & 2.026 & 1.58 & 2.621 & 2.242 & 2.079 & 2.103 \\
\hline Specific growth rate (\%) & 0.00 & 3.527 & 3.339 & 3.538 & 3.104 & 2.858 & 2.645 & 2.436 & 2.392 \\
\hline Mean growth rate (\%) & 0.00 & 0.687 & 0.580 & 0.511 & 0.451 & 0.393 & 0.347 & 0.310 & 0.286 \\
\hline Gross weight (g) & 0.00 & 59.187 & 49.777 & 49.33 & 43.387 & 29.234 & 26.541 & 19.585 & 35.636 \\
\hline Survival rate (\%) & 100 & 100 & 100 & 100 & 100 & 91.67 & 91.67 & 91.67 & 91.67 \\
\hline
\end{tabular}

Figure 2. Physiochemical parameter for treatment A (Coppens) (Weekly Mean Values).

\begin{tabular}{|c|c|c|c|c|c|c|c|c|}
\hline \multirow{2}{*}{ Physiochemical parameter } & \multicolumn{8}{|c|}{ Weeks } \\
\hline & 1 & 2 & 3 & 4 & 5 & 6 & 7 & 8 \\
\hline Atmospheric temperature $\left({ }^{\circ} \mathrm{C}\right)$ & 26.6 & 27.9 & 27.5 & 28.3 & 29.5 & 27.8 & 26.6 & 27.5 \\
\hline Water temperature $\left({ }^{\circ} \mathrm{C}\right)$ & 24.9 & 25.3 & 26.1 & 26.4 & 26.8 & 24.7 & 23.8 & 24.1 \\
\hline $\mathrm{pH}$ & 7.4 & 7.6 & 7.8 & 7.9 & 8.1 & 8.3 & 8.5 & 8.6 \\
\hline Dissolved Oxygen (mg/l) & 6.52 & 6.19 & 6.03 & 5.81 & 4.96 & 4.47 & 4.19 & 3.98 \\
\hline Ammonia (mg/l) & 0.01 & 0.12 & 0.19 & 0.26 & 0.34 & 0.41 & 0.44 & 0.45 \\
\hline Nitrite $(\mathrm{mg} / \mathrm{l})$ & 0.01 & 0.01 & 0.02 & 0.02 & 0.03 & 0.04 & 0.05 & 0.05 \\
\hline
\end{tabular}

chemical parameters for the treatments are given in (Tables 2, 4 and 6) respectively. Tables 1 and 2 show the production of and physiochemical parameters for treatment A (coppens), Tables 3 and 4 show the production and physiochemical parameters for treatment B (Bean Cake), and Tables 5 and 6 show the production and physiochemical parameters for treatment $\mathrm{C}$ (Multifeed) respectively. Also, Figures 1 to 7 show the graphical representations of the production and physiochemical parameters for treatment $A$; Figures 2 and 8 show the graphical representations for the production and physiochemical parameters for treatment $\mathrm{B}$; and Figures 3 and 9 show the graphical representations of the production and physiochemical parameters for treatment $\mathrm{C}$. However, (Figures 4, 5 and6) show the graphical representations of the survival rates, Specific Growth Rates (SGR) and Mean Growth Rates (MGR) for the three treatments respectively.
From (Figure 4), it can be observed that the fingerings survived at the same rate for the first two weeks, but treatment $B$ recorded mortalities on the 3rd and the 6th weeks, treatment $A$ also recorded a mortality on the 5th week and treatment $\mathrm{C}$ recorded a mortality on the 6th week. Figure 5 compare the Specific Growth Rates (SGR) of the three treatments. Treatments $A$ and $C$ showed a progressive decline on the SGR while treatment $B$ showed an increase on the SGR from 
Table 3. Production Parameters For Treatment B (Bean Cake).

\begin{tabular}{|c|c|c|c|c|c|c|c|c|c|}
\hline \multirow{2}{*}{ Production Parameters } & \multicolumn{9}{|c|}{ Weeks } \\
\hline & 0 & 1 & 2 & 3 & 4 & 5 & 6 & 7 & 8 \\
\hline Gross weight (g) & 118.452 & 126.684 & 140.916 & 146.52 & 158.532 & 174.988 & 172.21 & 184.31 & 199.80 \\
\hline Mean weight (g) & 9.871 & 10.557 & 11.743 & 13.320 & 14.412 & 15.908 & 17.221 & 18.431 & 19.980 \\
\hline Weight gain (g) & 0.00 & 0.686 & 1.182 & 1.577 & 1.092 & 1.496 & 1.313 & 1.210 & 1.549 \\
\hline Total length (cm) & 125.40 & 132.12 & 142.692 & 138.831 & 147.752 & 155.232 & 149.81 & 157.30 & 168.21 \\
\hline Mean length (cm) & 10.450 & 11.01 & 11.891 & 12.621 & 13.432 & 14.112 & 14.981 & 15.730 & 16.821 \\
\hline Length gain (cm) & 0.00 & 0.54 & 0.881 & 0.730 & 0.811 & 0.680 & 0.869 & 0.749 & 1.091 \\
\hline Specific growth rate (\%) & 0.00 & 0.960 & 1.240 & 1.427 & 1.351 & 1.363 & 1.325 & 1.274 & 1.259 \\
\hline Mean growth rate (\%) & 0.00 & 0.188 & 0.231 & 0.250 & 0.228 & 0.220 & 0.206 & 0.192 & 0.183 \\
\hline $\begin{array}{l}\text { Food conversion } \\
\text { efficiency (\%) }\end{array}$ & 0.00 & 14.478 & 23.326 & 27.978 & 19.472 & 23.591 & 19.197 & 17.566 & 21.011 \\
\hline Survival rate (\%) & 100 & 100 & 100 & 91.67 & 91.67 & 91.67 & 83.33 & 83.33 & 83.33 \\
\hline
\end{tabular}

Table 4. Physiochemical parameter for treatment B (Bean Cake) weekly mean values).

\begin{tabular}{|c|c|c|c|c|c|c|c|c|}
\hline \multirow{2}{*}{ Physiochemical parameter } & \multicolumn{8}{|c|}{ Weeks } \\
\hline & 1 & 2 & 3 & 4 & 5 & 6 & 7 & 8 \\
\hline Atmospheric temperature $\left({ }^{\circ} \mathrm{C}\right)$ & 26.5 & 27.1 & 28.1 & 26.4 & 27.5 & 27.1 & 26.3 & 27.4 \\
\hline Water temperature $\left({ }^{\circ} \mathrm{C}\right)$ & 24.9 & 25.3 & 24.1 & 25.4 & 25.6 & 24.7 & 25.2 & 25.1 \\
\hline $\mathrm{pH}$ & 7.4 & 7.6 & 7.8 & 8.1 & 8.4 & 8.6 & 8.7 & 8.9 \\
\hline Dissolved Oxygen (mg/l) & 6.73 & 6.01 & 5.31 & 5.02 & 4.50 & 4.31 & 4.06 & 3.49 \\
\hline Ammonia (mg/l) & 0.01 & 0.16 & 0.23 & 0.31 & 0.35 & 0.41 & 0.45 & 0.5 \\
\hline Nitrite (mg/l) & 0.01 & 0.02 & 0.02 & 0.03 & 0.05 & 0.07 & 0.09 & 0.11 \\
\hline
\end{tabular}

week 1 to week 3 and declined through to week 8 .

\section{Physiochemical parameters}

The atmospheric temperature throughout the study period varied between $26^{\circ} \mathrm{C}$ and $30^{\circ} \mathrm{C}$, while the water temperature varied between $23^{\circ} \mathrm{C}$ and $27^{\circ} \mathrm{C}$ (Tables 2, 4 and 6). The concentration of dissolved oxygen was between $6.73 \mathrm{mg} / \mathrm{l}$ and $3.49 \mathrm{mg} / \mathrm{l}$, which is within the permissible limit standard of dissolved oxygen for aquatic life recommended by the Federal ministry of Environment (2006). Also, Eding and Kamstra, (2001) reported that the standard value of dissolved oxygen for African catfish (Clarias gariepinus) is between 2.9 to $6.8 \mathrm{mg} / \mathrm{l}$. Treatment $B$ recorded the lowest amount of dissolved of oxygen $(3.4 \mathrm{mg} / \mathrm{l})$. The concentration of the dissolved oxygen declined weekly (Tables 2, 4 and 6) due to the growth of the fishes and therefore increases the demand for dissolved oxygen, was as the same volume of water is being used. Ammonia concentration in the three treatments throughout the experiment ranged between $0.01 \mathrm{mg} / \mathrm{l}$ and $0.5 \mathrm{mg} / \mathrm{l}$. Nitrite concentration ranged between 0.01 and 0.11 . Treatment $B$ 
Table 5. Production parameter for treatment C (Multi feed)

\begin{tabular}{|c|c|c|c|c|c|c|c|c|c|}
\hline \multirow{2}{*}{ Production parameters } & \multicolumn{9}{|c|}{ Weeks } \\
\hline & 0 & 1 & 2 & 3 & 4 & 5 & 6 & 7 & 8 \\
\hline Gross weight (g) & 122.16 & 147.792 & 173.976 & 204.12 & 242.412 & 271.932 & 272.041 & 296.791 & 326.282 \\
\hline Mean weight (g) & 10.180 & 12.316 & 14.498 & 17.010 & 20.201 & 22.661 & 24.731 & 26.981 & 29.662 \\
\hline Weight gain (g) & 0.00 & 2.136 & 2.182 & 2.512 & 3.191 & 3.460 & 3.07 & 3.25 & 2.681 \\
\hline Total length (cm) & 111.852 & 142.596 & 161.184 & 186.252 & 206.652 & 231.612 & 231.121 & 243.221 & 258.137 \\
\hline Mean length (cm) & 9.321 & 11.883 & 13.432 & 15.521 & 17.221 & 19.301 & 21.011 & 22.111 & 23.467 \\
\hline Length gain (cm) & 0.00 & 2.562 & 1.549 & 2.089 & 1.70 & 2.080 & 1.71 & 1.10 & 1.356 \\
\hline Specific growth rate (\%) & 0.00 & 2.721 & 2.526 & 2.445 & 2.447 & 2.286 & 2.114 & 1.989 & 1.910 \\
\hline Mean growth rate (\%) & 0.00 & 0.487 & 0.418 & 0.376 & 0.340 & 0.347 & 0.275 & 0.250 & 0.230 \\
\hline $\begin{array}{l}\text { Food conversion } \\
\text { efficiency (\%) }\end{array}$ & 0.00 & 43.713 & 36.910 & 36.097 & 39.082 & 35.683 & 28.224 & 29.867 & 22.583 \\
\hline Survival rate (\%) & 100 & 100 & 100 & 100 & 100 & 100 & 91.67 & 91.67 & 91.67 \\
\hline
\end{tabular}

Table 6. Physiochemical parameter for treatment C (Multi feed) weekly mean values.

\begin{tabular}{|c|c|c|c|c|c|c|c|c|}
\hline \multirow{2}{*}{ Physiochemical parameter } & \multicolumn{8}{|c|}{ Weeks } \\
\hline & 1 & 2 & 3 & 4 & 5 & 6 & 7 & 8 \\
\hline Atmospheric temperature $\left({ }^{\circ} \mathrm{C}\right)$ & 27.6 & 27.9 & 28.5 & 29.2 & 28.5 & 27.8 & 26.6 & 27.5 \\
\hline Water temperature $\left({ }^{\circ} \mathrm{C}\right)$ & 24.8 & 25.4 & 26.3 & 26.6 & 25.7 & 26.4 & 24.0 & 24.3 \\
\hline $\mathrm{pH}$ & 7.4 & 7.6 & 7.8 & 8.1 & 8.3 & 8.4 & 8.6 & 8.7 \\
\hline Dissolved Oxygen (mg/l) & 6.83 & 6.62 & 6.40 & 6.15 & 5.86 & 5.57 & 5.28 & 4.95 \\
\hline Ammonia (mg/l) & 0.01 & 0.13 & 0.18 & 0.27 & 0.35 & 0.42 & 0.46 & 0.47 \\
\hline Nitrite $(\mathrm{mg} / \mathrm{l})$ & 0.001 & 0.01 & 0.01 & 0.02 & 0.02 & 0.03 & 0.04 & 0.05 \\
\hline
\end{tabular}

recorded the highest value of nitrite concentration $(0.11 \mathrm{mg} / \mathrm{l})$.

\section{DISCUSSION}

The growth pattern in the three treatments revealed that the highest growth occurred in treatment $A$ and $C$ respectively. The reported crude protein value of fish in literature is $65 \%$ (Annune, 1990), while that of beans (vigna unguiculata) is $25 \%$ (Henshaw, 2008). Thus, from the above values, the feeds fed to treatment $A$ and $C$ has higher protein content than bean cake and therefore a higher biological value than bean cake, fact which is confirmed by fishes fed on coppen and multifeed which showed the highest weight gain. However, coppens had the highest weight gain $(4.759 \mathrm{~g})$, followed by Multi-feed $(3.460 \mathrm{~g})$ and then bean cake $(1.577 \mathrm{~g})$; length gain $(2.621 \mathrm{~cm}),(2.562 \mathrm{~cm})$ and $(1.091 \mathrm{~cm})$; specific growth rate $(3.572 \%),(2.721 \%)$, and $(1.427 \%)$; and mean growth rate $(0.687 \%)$, $(0.487 \%)$ and $(0.250 \%)$ (Tables 1,3 , and 5 ) respectively, this could be attributed to their difference in percentage of crude protein contents of the feeds, coppens (45\%), Multi-feeds (42\%) 

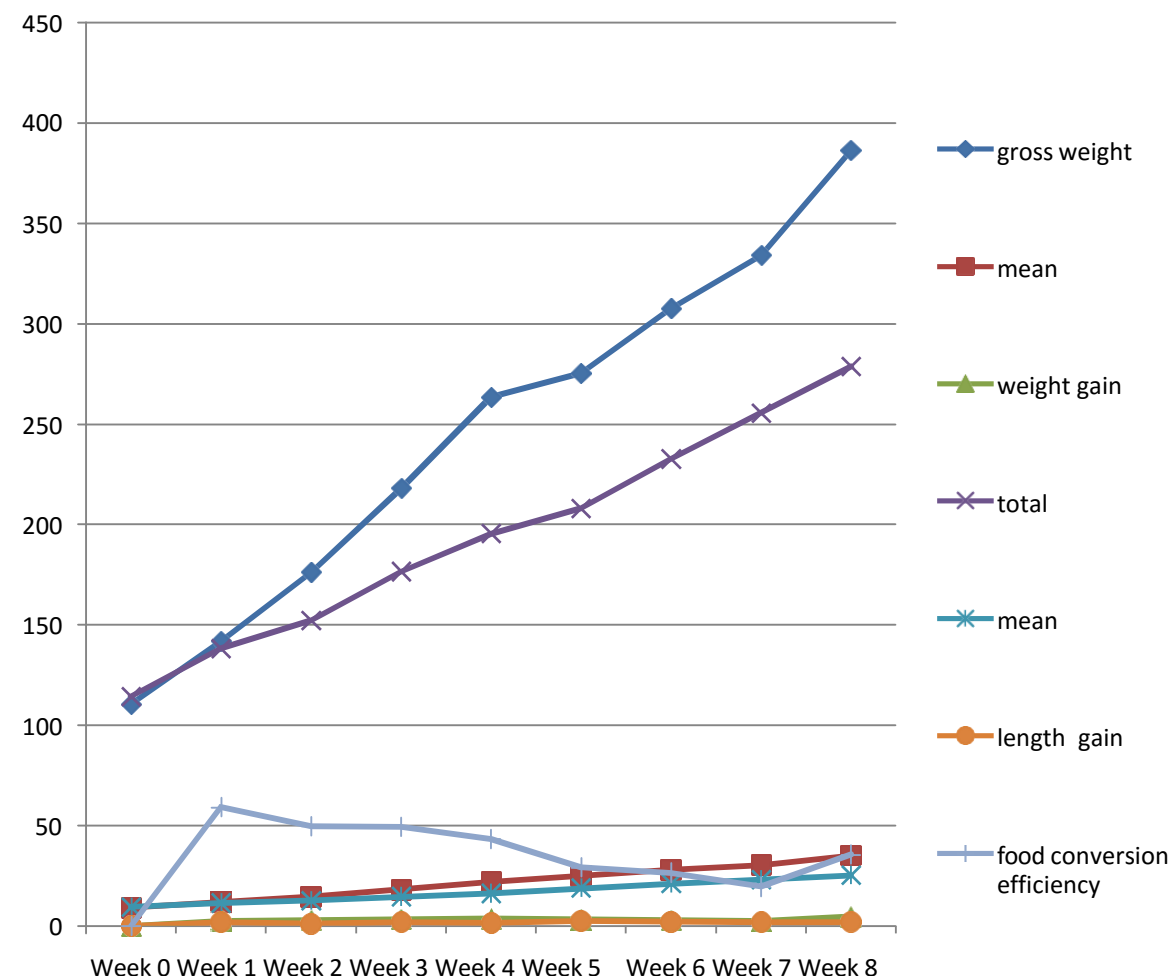

Figure 1. Production parameters for treatment $A$.

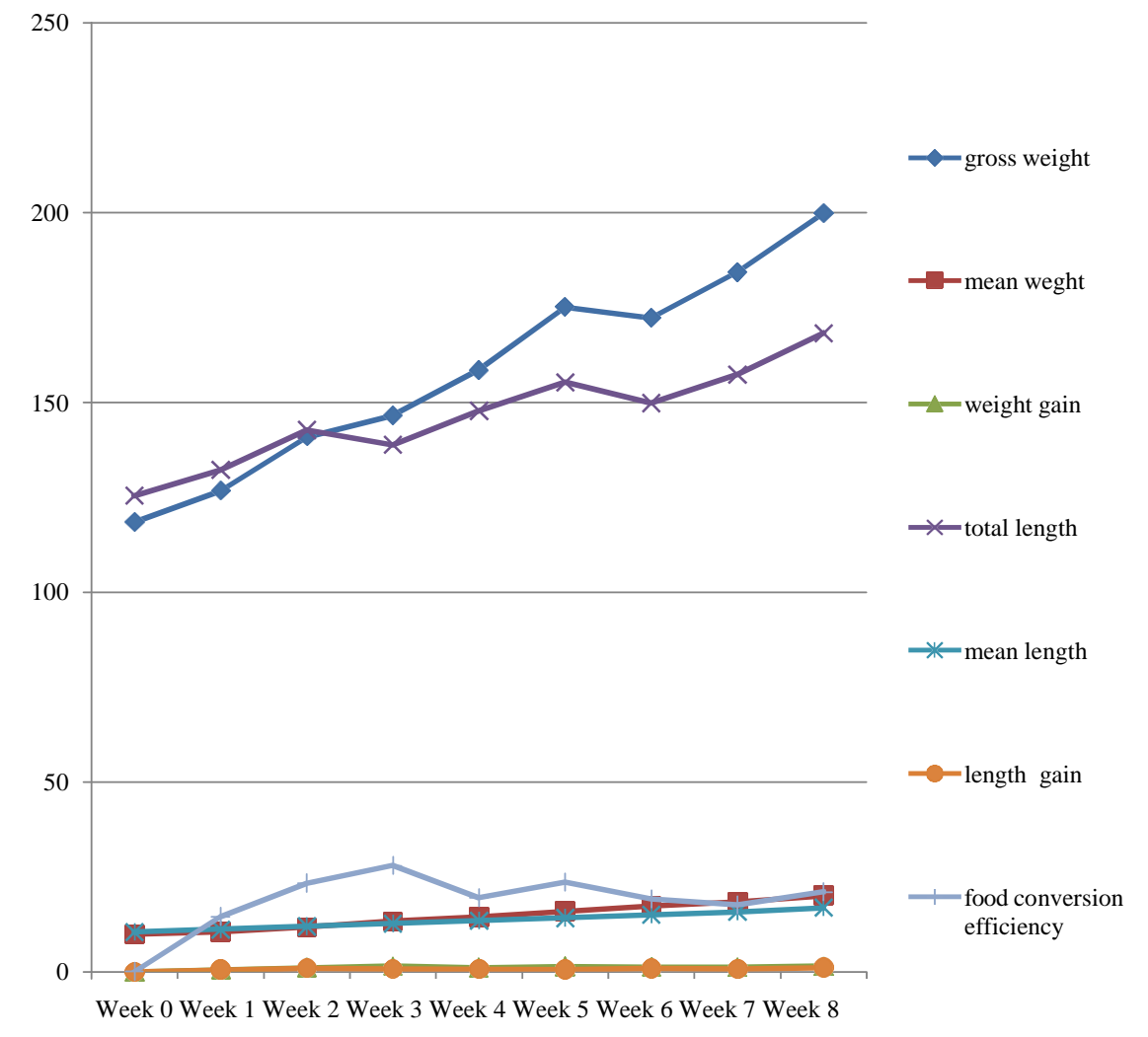

Figure 2. Production parameters for treatment B. 


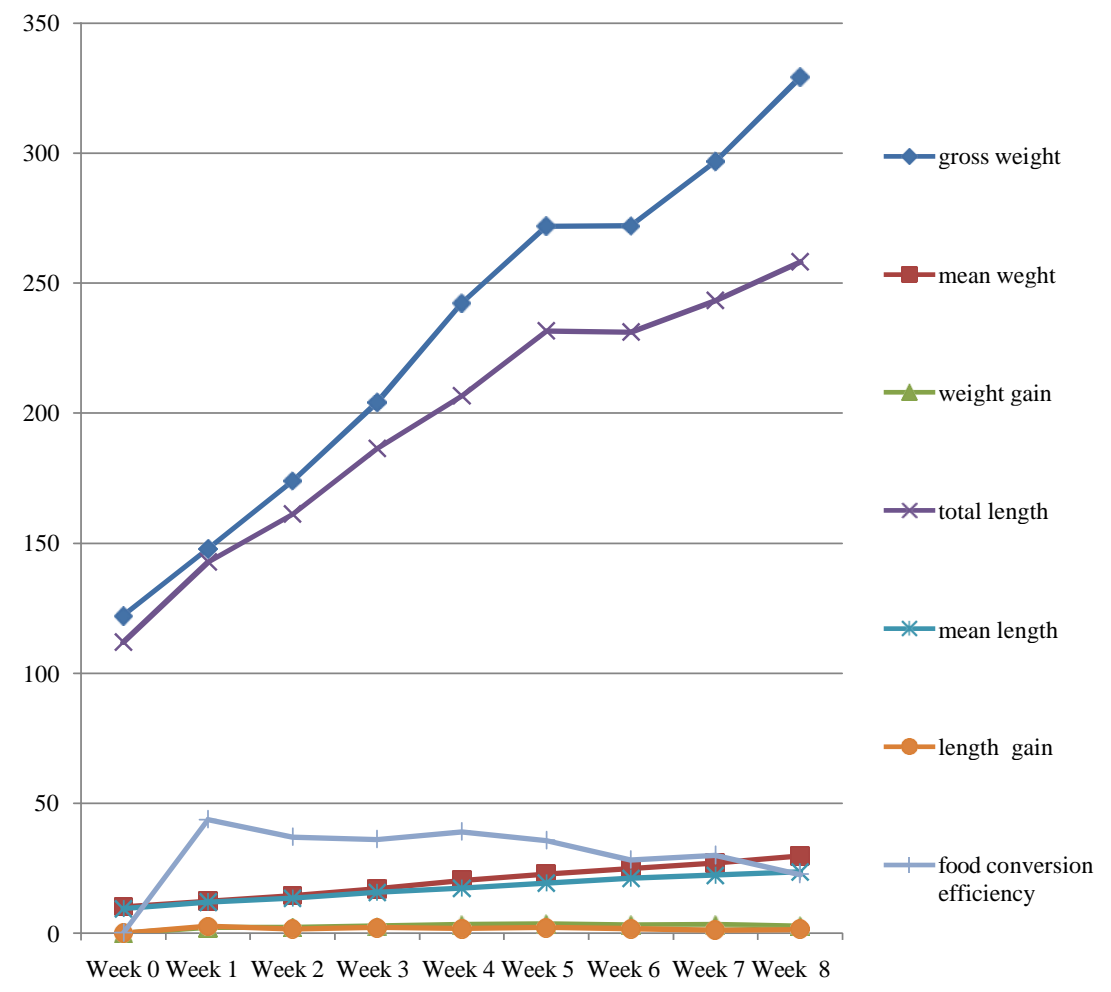

Figure 3. Production parameters for treatment C.

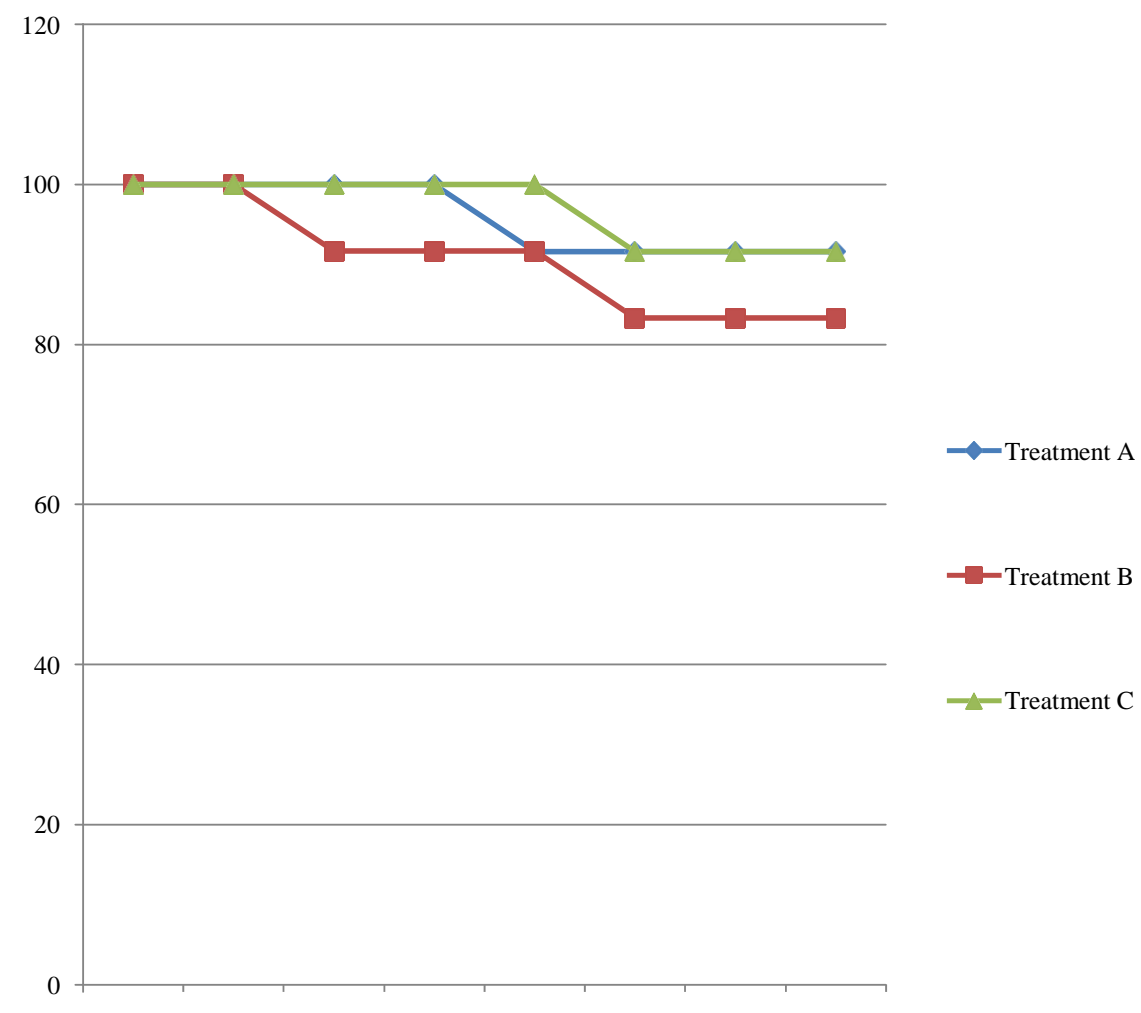

Week 1 Week 2 Week 3 Week 4 Week 5 Week 6 Week 7 Week 8

Figure 4. Survival Rates (\%) of the Treatments A, B and C. 


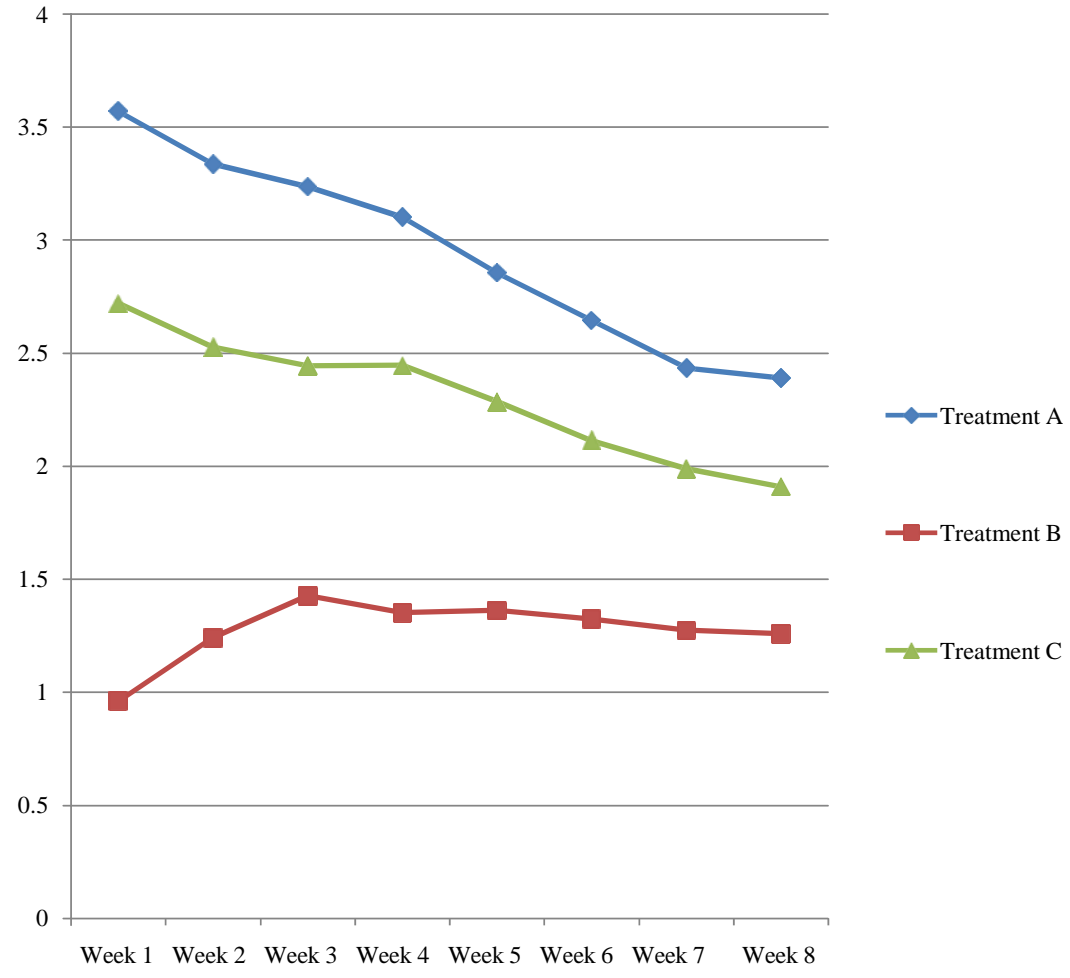

Figure 5. Specific Growth Rates (\%) of the three treatments.

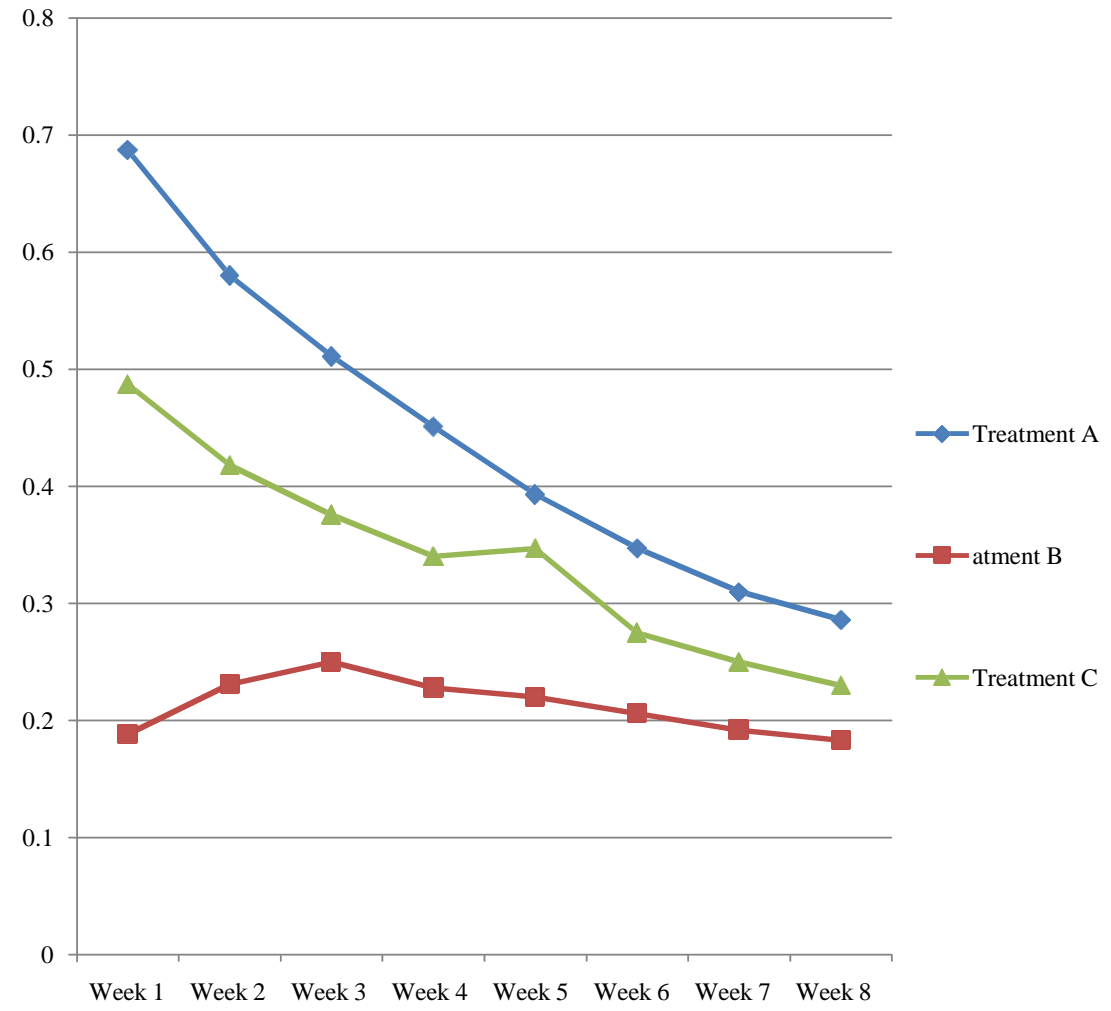

Figure 6. Mean Growth Rates (\%) of the three treatments. 


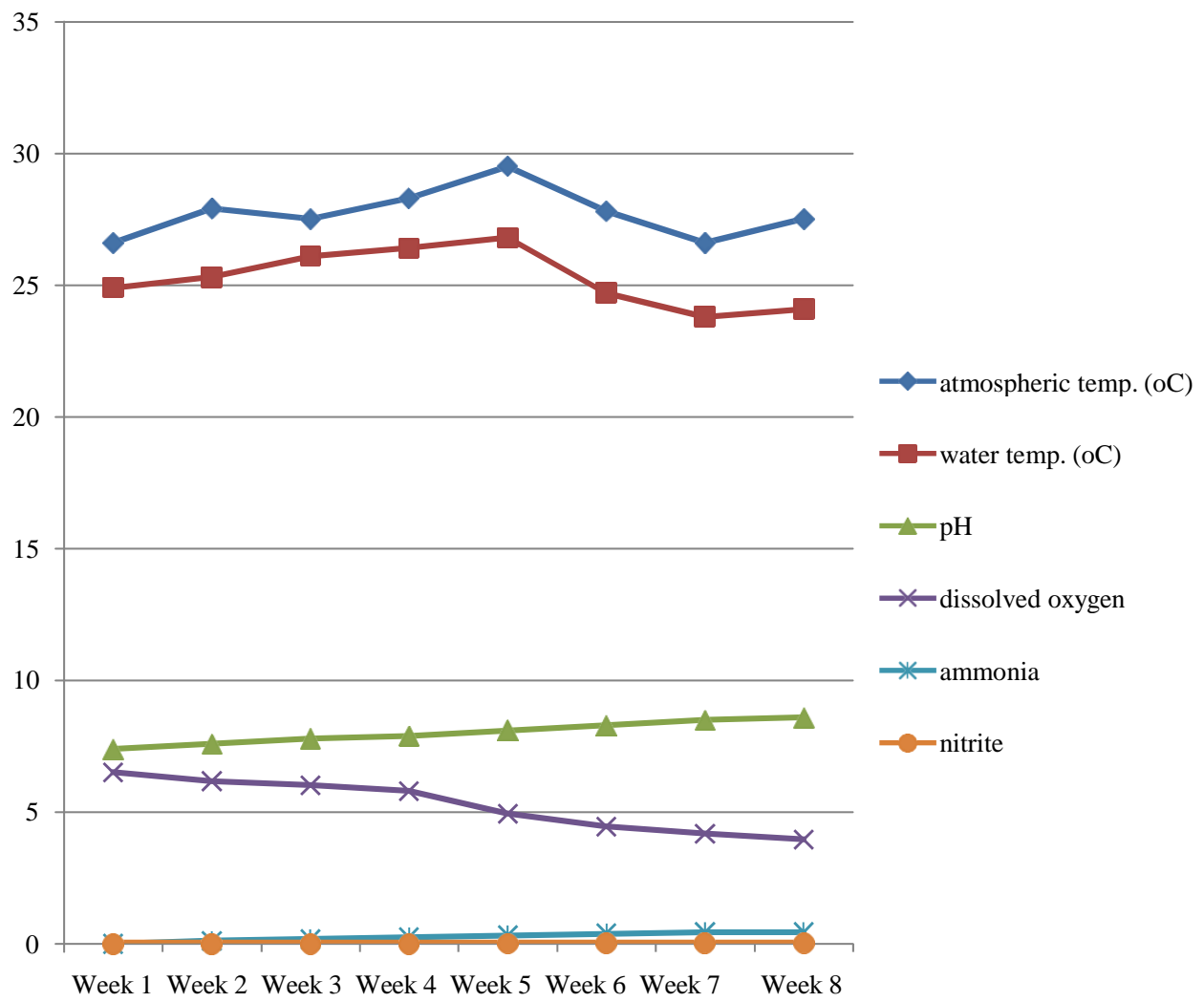

Figure 7. Physiochemical Parameters for treatments $\mathrm{A}$.

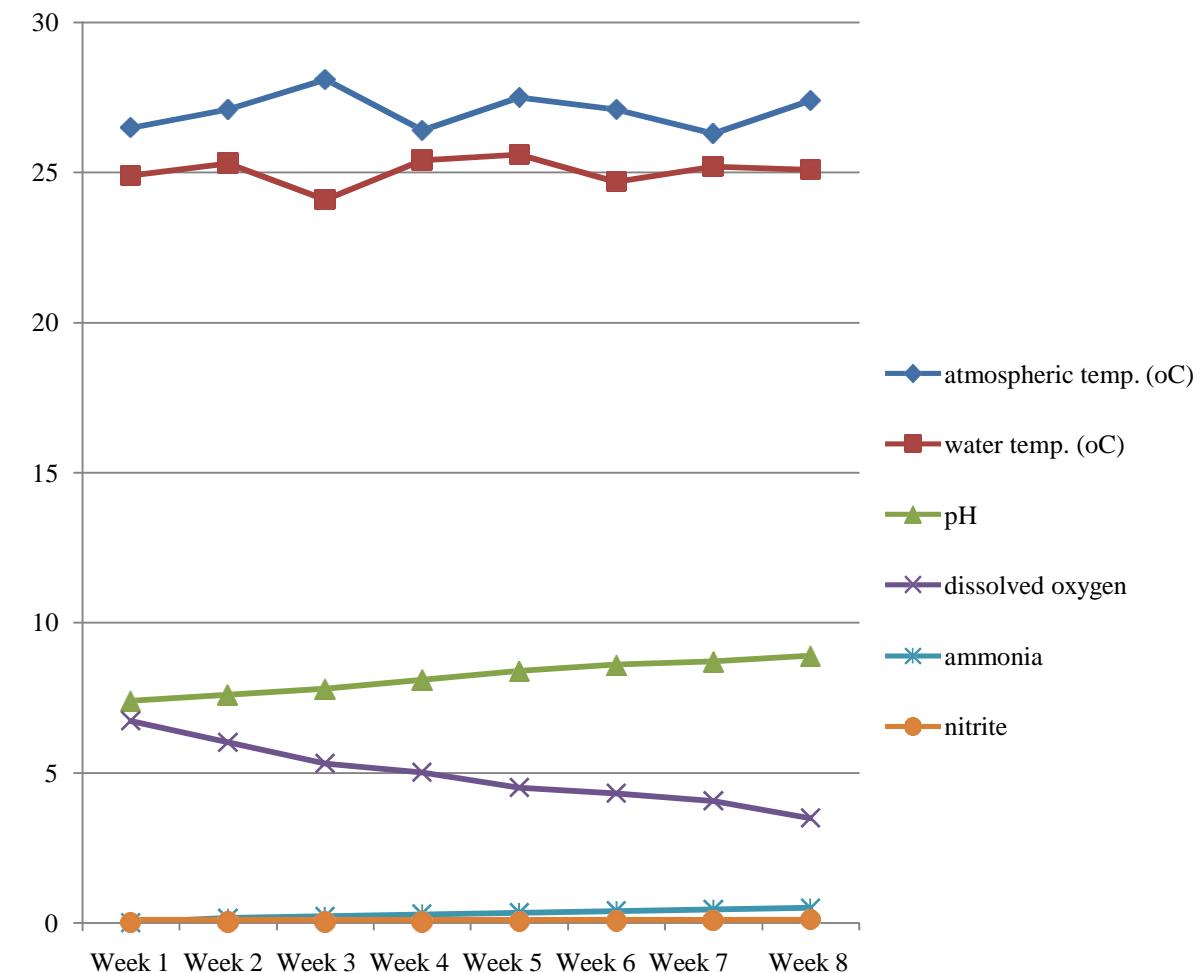

Figure 8. Physiochemical parameters for treatments B. 


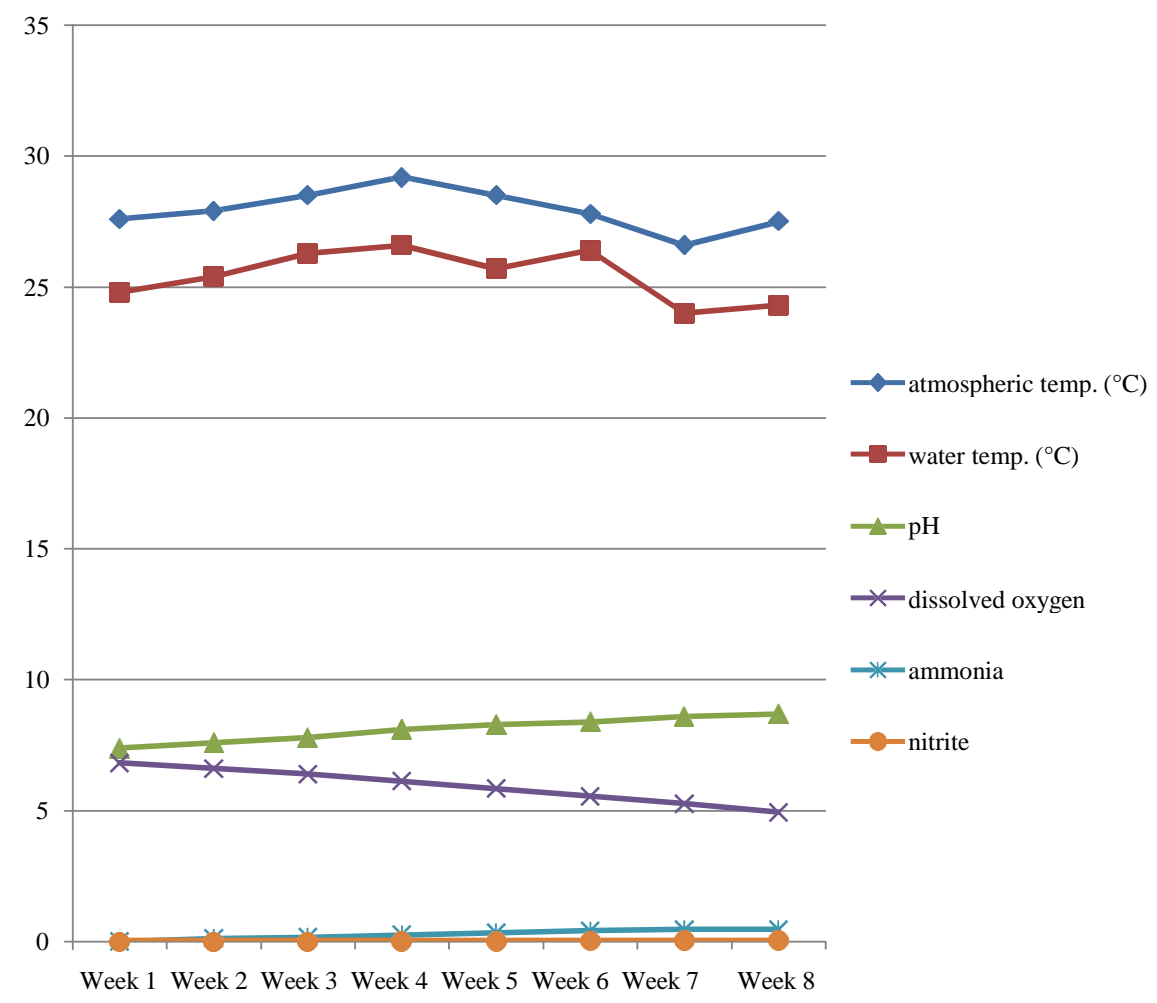

Figure 9. Physiochemical Parameters for treatments C.

and bean cake (28.6\%).

More so, another reason for the low performance of the fishes fed bean cake could be the lack of exudation of fish flavour from the diet (Chow, 1981), this then explains the low consumption rate of baen cake observed during the experiment and further explains why there was left over of feed in the aquarium with bean cake compared to others 15-20 min after they were fed.

The low consumption rate of bean cake could also be implicated in the low weight of observed and also the highest mortality rate recorded in Treatment B from the inception of the experiment to its termination. The effect of bean cake and the other feeds on the growth and productivity of Clarias gariepinus was statistically analysed using the one-way ANOVA. The analysis showed that there was a significant difference in weight gain $(F=7.596155 ;$ df $=24 ; \mathrm{P}$-value $=0.00278$; $P<0.05)$, length gain $(F=6.9350852 ; d f=24 ; P$-value $=$ $0.004209 ; P<0.05)$, Specific growth rates $(F=5.310648$; $\mathrm{df}=24 ; \mathrm{P}$ - value $=0.012314 ; \mathrm{P}<0.05)$, Mean growth rate $(F=4.535696 ; \mathrm{df}=24 ; \mathrm{P}$-value $=0.021336 ; \mathrm{P}<0.05)$.

However, the analysis showed that there was no significant difference in mean weight $(\mathrm{F}=2.611572 ; \mathrm{df}=$ 24; $\mathrm{P}$-value $=0.094148 ; \mathrm{P}>0.05)$, mean length $(\mathrm{F}=$ $2.022346 ; \mathrm{df}=24 ; \mathrm{P}$-value $=0.154286 ; \mathrm{P}>0.05)$, food conversion efficiency $(F=3.370884 ; \mathrm{df}=24 ; \mathrm{P}$-value $=$ $0.051261 ; P>0.05)$, survival rate $(F=2.697197$, $d f=24$; $\mathrm{P}$-value $=0.08773 ; \mathrm{P}>0.05)$.

\section{Conclusion}

It is however concluded from the experiment that bean cake feed does not contain the nutrient necessary for the optimum growth and development of Clarias gariepinus, but contains nutrients for the maintenance and the sustenance of Clarias gariepinus and is therefore recommended to be used for the maintenance of Clarias gariepinus, because it is less expensive and readily available.

\section{CONFLICT OF INTEREST}

The authors declare that they have no conflict of interest.

\section{REFERENCES}

AFP (2004). Inventory of feed producers in Nigeria. Published by aquaculture and inland fisheries project. Annex of the National special programme for food security with the Agriculture development programme in all states and FCT Abuja, Nigeria. p. 118.

Akinwole, A. O., \& Faturoti, E. O. (2006). Biological performance of African Catfish (Clarias gariepinus) cultural in recirculating system in Ibadan. Aquacultural Engineering, 36, 18-23.

Akiyama, D. M. (1988). Soybeans meal utilization in fish feed 
paper presented at the Korean feed Association; Conference. August, 1988, soule. Korea. p. 9.

American Public Health Association (1976). Standard methods for the examination of water and waste water, 14th Edition. APHA, New York,N.Y. p. 119.

Annune, P. A. (1990). Preliminary Investigation on the suitability of toad meal Bufo regulars in the diet of catfish, Clarias lazera, Journal of Aquatic Science. 5, 37-42.

Anon (1997). Communication from the commission to the council and the European parliament commission. European commission Brussels. p. 20.

Aremu, C. Y. (1990). Proximate and amino acid composition of cowpea (Vigna unguiculata, walp) protein concentrate prepared by isoelectric point precipitation. Food Chemistry, 37(1), 61-68.

Ayinla, O. A., \& Akande, G. R. (1988). Growth response of Clarias gariepinus on silage based diets. Nigeria Institute of Oceanography and Marine Research. Technical Paper, 62, 15.

Balogun, A. M., \& Faturoti, E. O. (1992). Nutrient utilization and growth responses of Clarias gariepinus with different dietary protein levels. Nigeria Journal of Applied fish Hydrobiology. 1, 41-45.

Bene, C., \& Heck, S. (2005). Fisheries and the millennium development goals: solutions for Africa. Naga, Worldfish Center Quarterly, 28(3-4), 14-18.

Boyd, C. E. (1982). Water quality in pond for aquaculture. Auburn university, Auburn. Pp. 359.

Changadeya, W., Malekano, L. B., \& Ambali, A. J. D. (2003). Potential of genetics for aquaculture development in Africa. Naga, Worldfish Center Quarterly, 26(3), 31-35.

CIFA (1998). A strategic reassessment of fish farming potential in Africa. CIFA Technical paper. 32:1-15.

Dada, B. F., \& Gnanados D. A. S. (1983). Nigerian fisheries Dev't challenges and opportunity of the 1980s. A paper presented at the 3rd National Conference of fisheries society of Nigeria, Maiduguri. 22nd - 25th. Feb.

Dengani, S. K., \& Akambo, P. M. (1989). Protein requirement of some African fishes. A paper presented at the 4th annual conference of fisheries society of Nigeria held in lagos, January 15 th -18 th 1984 . Pp. 1-19.

Devendra, C. (1985). Non-conventional feed resources in Asia and the pacific, 2nd edition FAO/APACA. Publication No. 6, Bangkok. Pp. 6-22.

Eding, C., \& Kamstra, G. (2001). Design and Performance of Recirculation Systems for European eel Anguilla and African catfish Clarias gariepinus in: Proceeding of AES Workshop. Florida, USA, Pp. 18-28.

Engel C. R. (1997). Optional resources allocation by fish farmers in Rwanda. Applied Aquaculture. 7, 1-17.
Eyo, A. A. (1990). Some aspects of utilization of soya bean meal by young mud fish (Clarias anguillaris). Unpublished phD thesis, Ahmadu Bello University Zaria.

Falaye, A. E. (1992). Utilization of agro-industrial wastes as fish feed stuff in Nigeria. p. 47-57. In: Eyo, A. A, Balogun, A.M. (eds.). Proceedings of the 10th annual conference of the fisheries society of Nigeria Abeokuta. p. 262.

FAO (1996a). Food for All Poor issued on the occasion of the world food summit in Rome. FAO Rome, p. 64.

FAO (1996b). Poverty and food security in Africa. Documentation issued on the occasion of the world food summit in Rome. FAO Rome, p. 64.

FAO (1997). AFRICOVER, land cover classification. FAO, Rome, p. 64.

FAO (2003). Fisheries Statistics http://www.fao.org.

FAO, (1996c). Aquaculture potential in Africa documentation issues on the occasion of the world summit in Rome. Rome $\mathrm{FAO}$, p. 20.

Federal ministry of environment (2006). National guideline and standard for water quality in Nigeria. p. 40.

Henshaw, F.O. (2008). Varietal differences in physical characteristics and proximate analysis of cowpea (Vigna unguiculata). World journal of agricultural sciences. 4(3), 302306.

Hetch, T. (2000). Consideration on Africa aquaculture. J. world Aquaculture, 31, 12-19.

Ita, E. O., Sado, E. K., Balogun, J. K., Pandogari, A., \& Ibitoye, B. (1985). A preliminary checklist of inland water bodies in Nigeria with special reference to lakes and reservoirs. Kainji Lake Research Institute, Kainji, Technical Report, p. 14.

Jamiu, D. M., \& Ayinla O. A. (2003). Potential for the development of aquaculture in Africa NAGA. 26(3), 9-13.

Kapetsy, J. M. (1994). A strategic assessment of warm water fish farming potential in Africa. CIFA Technical Paper No. 27. FAO Rome. p. 67.

Muir, J. F., Gitonga, N., Omar, I., Pouomogne, V., \& Radwan, I. (2005). Hidden harvests: Unlocking the potential of aquaculture in Africa. Technical Review Paper. NEPAD-Fish for All Summit, Pp. 22-25.

Singh, B. (2003). Improving the production and utilization of cowpea as food and fodder. Field crops research. 84, 146150.

Sterling, H. R. (1985). Chemical and biological methods of water Analysis for Aquaculturists. 1st edition. Institute of Aquaculture, University of Stirling, Great Britain. p. 119.

Ugwumba, A. A. A., \& Ugwumba, A. O. (2003). Aquaculture options and the future of fish supply in Nigeria. The Zoologist, 2(2), 96-122. 